\title{
MYRMECOLOGICAL NOTES
}

\author{
By William Morton Wheeler \\ Biological Laboratories, Harvard University
}

1. New Subgenera OF Dolichoderinae.

The genus Dolichoderus Lund (1831) now comprises more than 150 described species, subspecies and varieties. While revising these forms I have found it advisable to add to the number of subgenera recognized by Emery in his already somewhat antiquated fascicle on the Dolichoderinæ in the "Genera Insectorum" (1912). He accepted only three genera, Dolichoderus sens. str., Monacis Roger (1862) and Hypoclinea Mayr (1855). The first and second restricted to tropical America, contain comparatively few species and are clearly defined. All the remainder were assigned to $\mathrm{Hy}-$ poclinea, which is very heterogeneous and much more widely distributed, since it is represented in all the great zoögeographical regions, except Africa and Oceania. More recently (1926) Karawajew has established another subgenus, Diabolus, on what he erroneously supposed to be an undescribed species from Java. I adopt this subgenus, however, and propose three others for as many groups of East Indian, Papuan and Australian species formerly assigned to Hypoclinea. These subgenera, which are here listed are characterized like Dolichoderus sens. str. and Monacis, by peculiarities of the thoracic armature:

Monoceratoclinea subgen. nov. Subgenotype: Dolichoderus (Hypoclinea) monoceros Emery (1897). Other species: D. (H.) tricornis Emery.

Habitat: New Guinea.

Diabolus Karawajew (1925). Subgenotype: Polyrchachis cuspidatus F. Smith (1857) (This subgenus was based on D. (Diabolus) bifurcatus Karawajew, which is synonymous with D. (H.) cuspidatus surbecki Santschi (1925). Other species: furcifer Emery and coniger Mayr.

Habitat: Indonesia. 
Diceratoclinea subgen. nov. Subgenotype: Dolichoderus scabridus Roger (1826). Other species: beccarii Emery, angusticornis Clark, indrapurensis Forel, ypsilon Forel.

Habitat: Australia and Indonesia.

$D$. cornutus Mayr of the Baltic Amber also belongs to this subgenus.

Acanthoclinea subgen. nov. Subgenotype: Dolichoderus doriæ Emery (1887). Other species: edentata Forel, extensispinosa Forel and clarki nom. nov. for D. tristis Clark (1930) nec. D. (Monacis) tristis Mann (1916).

Habitat: Australia.

Unfortunately, these subgenera only slightly reduce the number of species in Hypoclinea. We may follow Emery in distinguishing four geographical groups in this subgenus, a holarctic (to which the name Hypoclinea properly belongs, since the Eurasian quadripunctatus L. is the subgenotype) a Neotropical, an Indomalayan and an Australian, but I have not been able to discover in the workers any characters that would justify further subgeneric division. This may be possible when the sexual phases are better known. That the females may possess characters of taxonomic value is suggested by Acanthoclinea. Though colonies of this subgenus are not uncommon in Eastern Australia, no one has ever seen a winged female of any of the species. Very recently, however, Clark (Mem. Nat. Mus. Melbourne No. 8, 1934, p. 40, pl. 3, fig. 6) has described and figured a peculiar ergatoid female from a colony of dorix. It is not improbable, therefore, that this is the typical and only form of female in the subgenus as it is in Leptomyrmex and several other Australian ant-genera.

\section{The Tribe of Melophorini Forel.}

According to Emery, (Gener. Insect. 1927), this the most primitive tribe of Formicine ants comprises only two genera, Melophorus Lubbock and Notoncus Emery, but it needs revision both by subdivision of the old genus Melophorus and by addition of two other genera. One of these is Myrmecorhynchus for which I made a special tribe in 1917. In this I was followed by Emery, but I am now convinced that Mrymecorhynchus is a Melophorine. Clark has recently 
added another genus, Pseudonotoncus, which is related to Notoncus. I find that specimens of the type, Ps. hirsutus Clark, which long awaited description in my collection, have a typical Melophorine gizzard. Diodontolepis, a genus, which I based on Melophorus spinisquamis Ern. André in 1922, was again merged with Melophorous by Emery in 1927 , but this was a blunder, as any myrmecologist who has seen specimens of the insect will admit. According to Clark, its habits too, differ from those of Melophorus.

The old genus Melophorus was divided by Emery into three subgenera: Melophorus sens. str., Prolasius Forel and Lasiophanes Emery. In this he followed Forel (1911) who had declined to split the genus though he was impressed by the heterogeneity of the species, some of which he characterized as Cataglyphis-like, others as Pheidole-like and still others as Formica- and Lasius-like. I believe that Prolasius and Lasiophanes which have monomorphic lasiiform or formiciform workers should be regarded as distinct though very closely related genera of Antarctic origin. Up till 1934 only one species had been assigned to Prolasius, namely $P$. advena of New Zealand, but I found in 1931 that several of the Australian species placed by Forel and Emery in Melophorus clearly belong to Prolasius, and Clark has very recently described several others. The true Melophori, thus restricted to species with polymorphic workers, may be divided into three subgenera mainly on thoracic structure, namely Melophorus sens. str. comprising the Cataglyphis-like forms, Erimelophorus subgen. nov. the Pheidolelike forms with huge-headed maxima workers, and Trichomelophorus subgen. nov. for M. hirsutus Forel and its varieties. This subgenus is characterized also by peculiar sculpture and very long dense pilosity. The following therefore represents my conception of the generic and subgeneric composition of the tribe Melophorini :

Genus Lasiophanes Emery (1895).

Genotype: Formica nigriventris Spinola (1851). Other species: bruchi Forel, bolivari Santschi, hoffmanni Forel, perplexus Santschi, picinus Roger, sauteri Forel, uxorius Emery, valdiviensis Forel, edwardsi Donisthorpe, negrensis Donisthorpe, rufoniger Donisthorpe. 
Habitat: Patagonia, Argentina, Chile.

Genus Prolasius Forel (1892).

Genotype: Formica advena F. Smith (1862) of New Zealand. Australian species: depressiceps Emery, formicoides Forel, mjöbergiellus Santschi, nitidissimus Ern. André, scipio Forel, abruptus Clark, pallidus Clark, hemiflavus Clark, niger Clark, flavicornis Clark, hickmani Clark, rotundiceps Clark.

Genus Melophorus Lubbock (1883).

Habitat: Australia.

Melophorus (subgen. emend.). Subgenotype: M. bagoti Lubbock (1883). Other species: aeneovirens Lowne, curtus Forel, constans Santschi, iridescens Emery, insularis Wheeler.

Erimelophorus subgen. nov. Subgenotype: M. wheeleri Forel (1910). Other species : biroi Forel, fieldi Forel, marius Forel, mjöbergi Forel, omniparens Forel, pillipes Santschi, laticeps Wheeler, turneri Forel.

Trichomelophorus subgen. nov. Subgenotype:

$M$. hirsutus Forel (1902).

Genus Diodontolepis Wheeler (1922).

Genotype: Melophorus spinisquamis Ern. André (1896).

Habitat: Eastern Australia.

Genus Pseudonotoncus Clark (1934).

Genotype: Ps. hirsutus Clark (1934).

Habitat: Southeastern Australia.

Genus Notoncus Emery (1895).

Genotype: Notoncus ectatommoides Forel (1892). Other species: capitatus Forel, enormis Szabó, foreli Ern. André, gilberti Forel, mjöbergi Forel, politus Viehmeyer.

Habitat: Australia.

Genus Myrmecorhynchus Ern. André (1896).

Genotype: $M$. emeryi Ern. André (1896). Other species: carteri Clark, musgravei Clark, nitidus Clark, rufithorax Clark.

Habitat: Eastern Australia.

\section{Some Preoccupied Names.}

In addition to Karawajew's and Clark's homonyms cited above, I would call attention to the following, which I have discovered in my own writings on other genera:- 
Acropyga (Rhizomyrna) indosinenis nom. nov. for

$A$. (R.) silvestri Wheeler (1927) nec. A.

(Malacomyrma) silvestri Emery (1915).

Nylanderia consuta nom. nov. for $N$. dicroa Wheeler (1934). nec. N. dichroa Karawajew (1933).

Camponotus (Myrmocladoecus) sanctae-fidei weberi nom. nov. for C. (M.) sanctae-fidei darlingtoni (Nov. 1934). nec. C. (Myrmophyma) darlingtoni Wheeler (Oct. 1934).

Ponera leæx norfolkensis nom. nov. for P. leae oculata

Wheeler (1927) nec Ponera oculata F. Smith (1858). 

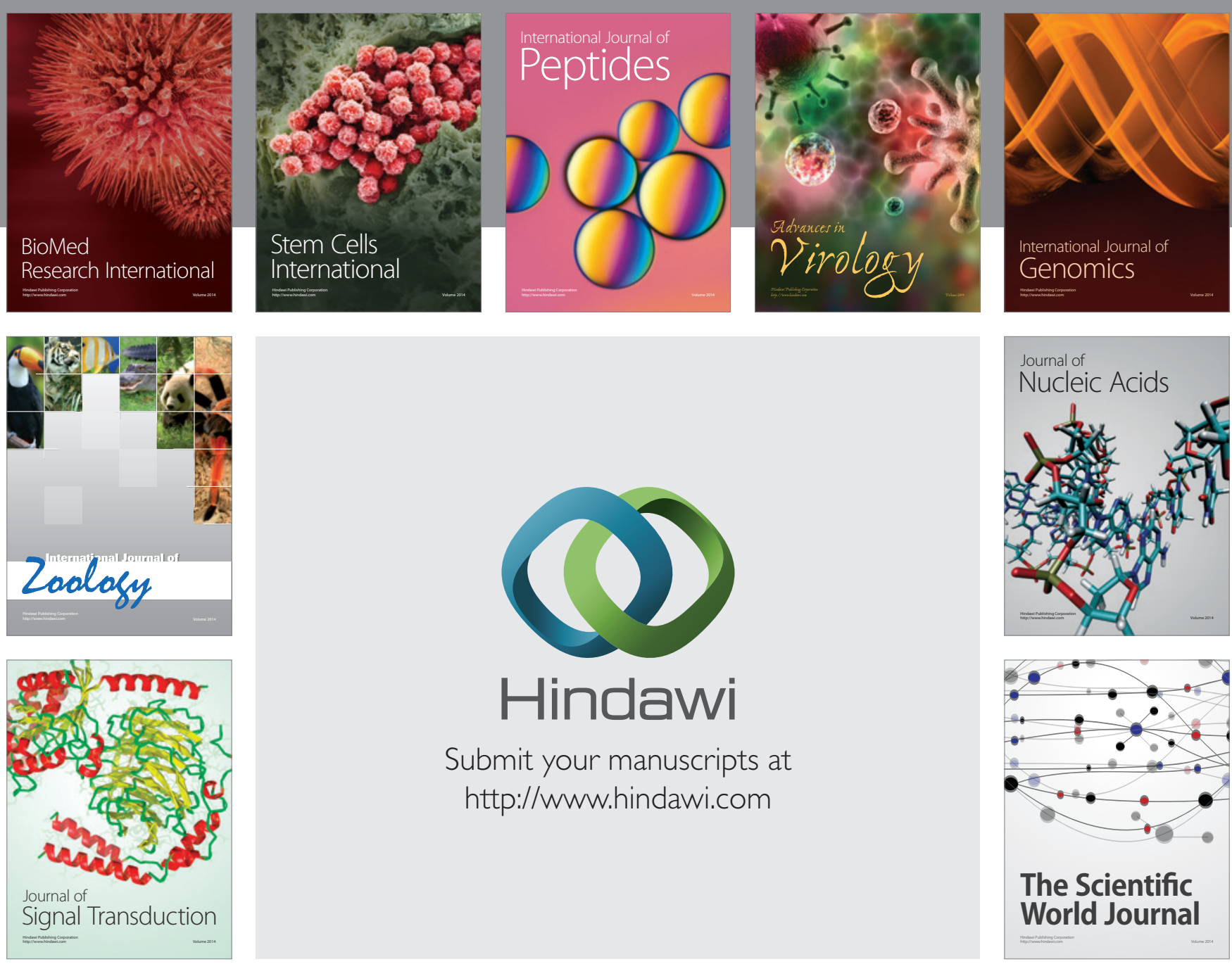

Submit your manuscripts at

http://www.hindawi.com
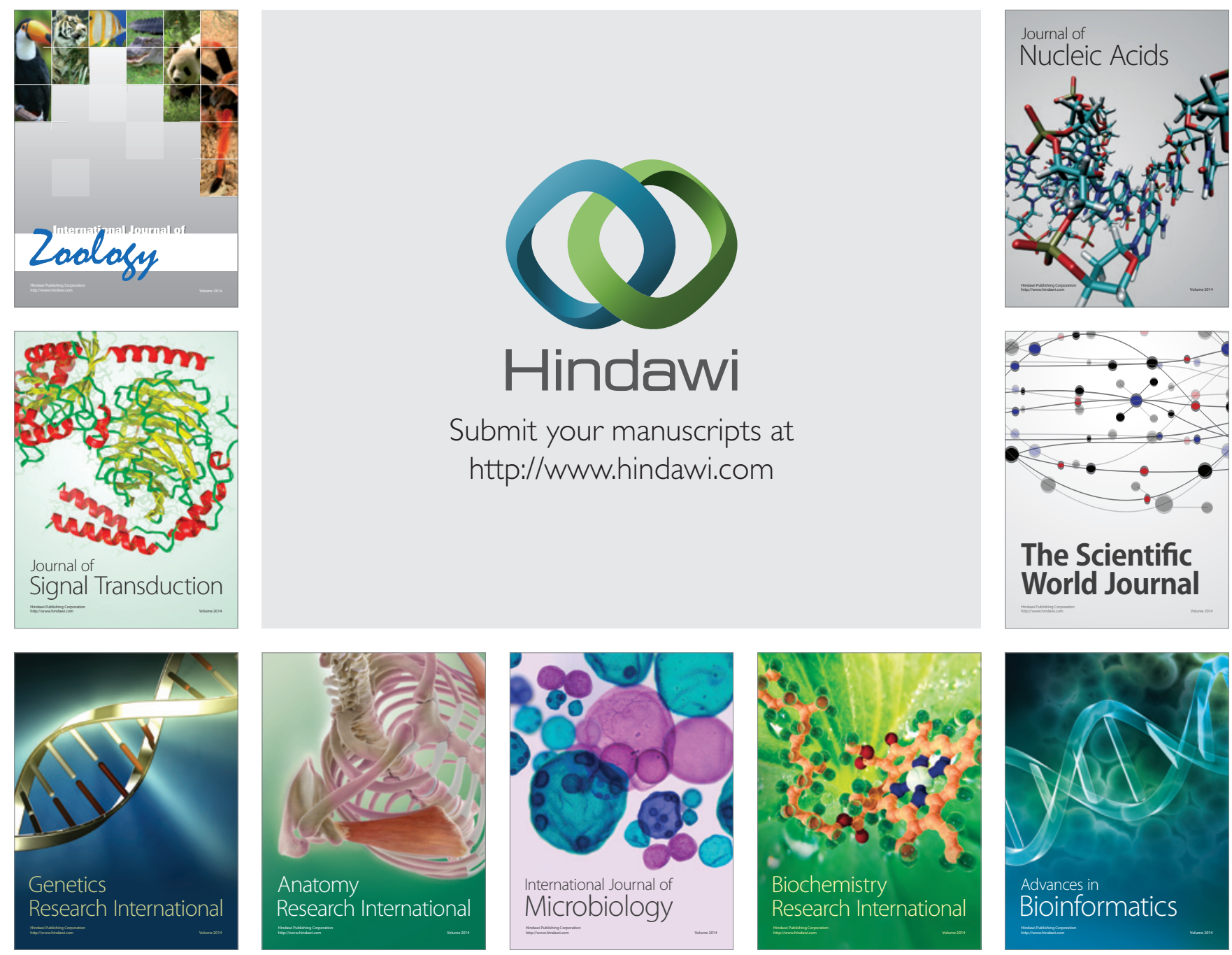

The Scientific World Journal
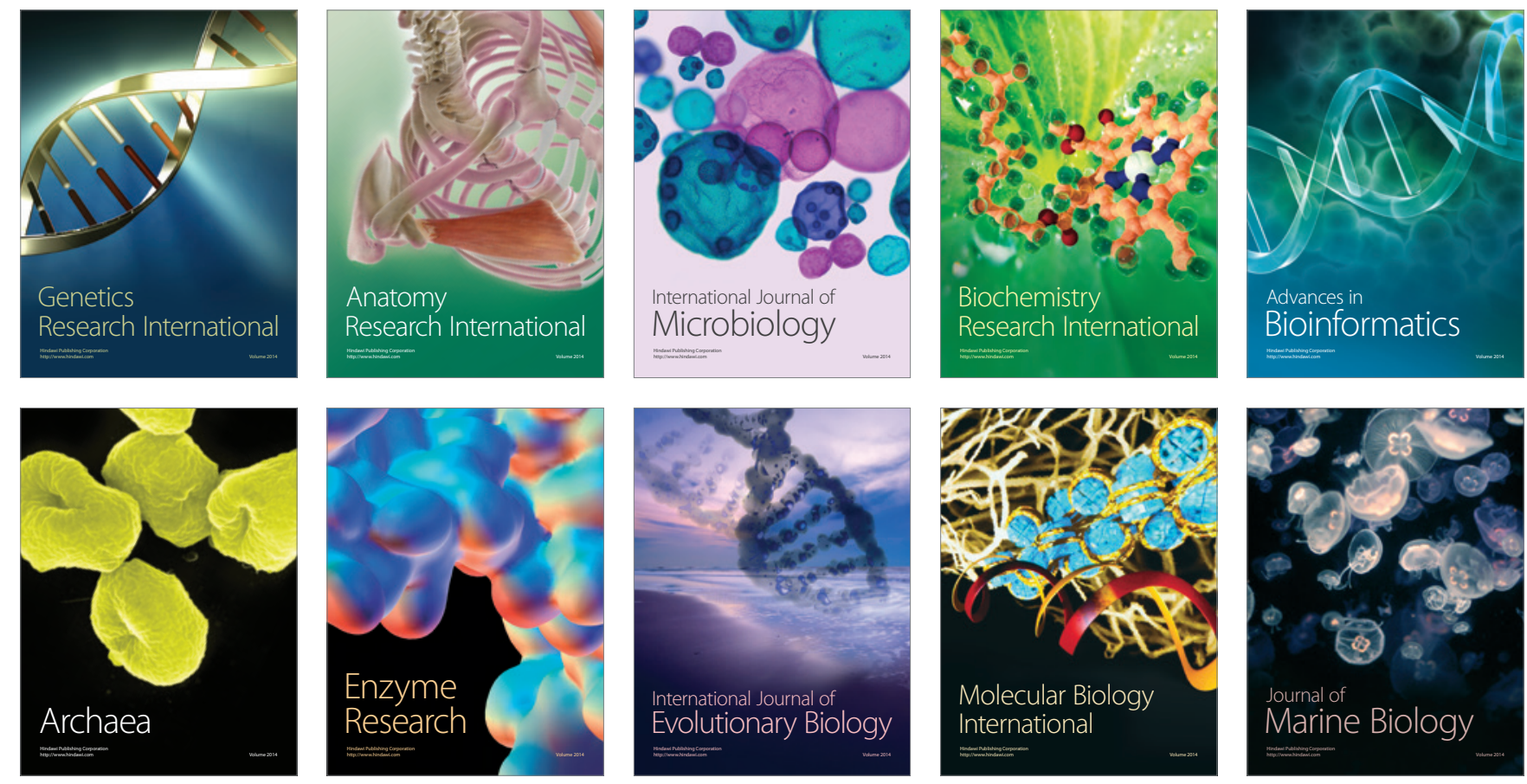